\title{
PENGEMBANGAN MEDIA PEMBELAJARAN INTERAKTIF PADA MATA PELAJARAN FISIKA
}

\author{
Intan Permata Putri dan Abdul Muin Sibuea \\ MTsN 3 Medan dan PPs Universitas Negeri Medan \\ intan.permata.putri@gmail.com
}

\begin{abstract}
Abstrak: Penelitian ini bertujuan untuk menghasilkan media pembelajaran interaktif macromedia flash yang layak digunakan, mudah dipelajari, mengetahui hasil pembelajaran menggunakan media pembelajaran interaktif macromedia flash, dan mengetahui keunggulan media pembelajaran interaktif macromedia flash jika dibandingkan dengan power point. Jenis penelitian ini adalah penelitian pengembangan. Data kualitas produk pengembangan dikumpulkan dengan angket dan dianalisis secara deskriptif kualitatif. Hasil penelitian menunjukkan bahwa uji ahli; materi pelajaran desain pembelajaran, rekayasa perangkat lunak berkualifikasi baik, uji coba perorangan, uji coba kelompok kecil, dan uji coba lapangan kualifikasi sangat baik. Uji keefektifan produk dilakukan dengan metode kuasi eksperimen. Hasil penelitian menunjukkan terdapat perbedaan hasil belajar antara siswa yang dibelajarkan menggunakan media pembelajaran interaktif dengan menggunakan media powerpoint yaitu rata-rata hasil belajar siswa yang dibelajarkan dengan menggunakan media pembelajaran interaktif lebih tinggi dibandingkan dengan siswa yang dibelajarkan dengan menggunakan media powerpoint.
\end{abstract}

Kata Kunci: pengembangan media pembelajaran interaktif dan media power point, hasil belajar fisika

\begin{abstract}
This research aims to produce interactive learning media macromedia viable use, easy to learn, to know the learning outcomes using macromedia flash media interactive learning, and know the benefits of interactive learning media macromedia flash when compared to the power point. This type of research is the development of research. Data collected by the quality of the product development questionnaire and analyzed by descriptive qualitative. The results showed that the expert test; the subject matter of instructional design, software engineering well qualified, individual testing, piloting small groups, and field trials are very well qualified. Test the effectiveness of the products made by the method of quasi-experimental. The results showed there were differences in learning outcomes between students that learned to use interactive learning media using powerpoint media which is an average student learning outcomes that learned by using interactive learning media is higher than students who learned with using powerpoint media.
\end{abstract}

Keywords: development of interactive learning media and media power point, the result of learning physics

\section{PENDAHULUAN}

Fisika merupakan ilmu yang termasuk rumpun IPA, dan dalam pelaksanaan proses pembelajaran fisika yang selama ini berlangsung menunjukkan bahwa sebagian besar siswa tampak kurang berminat, kurang bergairah dan cenderung tidak aktif. Hal ini ditunjukkan oleh sikap siswa yang kurang antusias ketika pembelajaran akan berlangsung, rendahnya respon umpan balik dari siswa terhadap pertanyaan dan penjelasan guru, kurangnya pemusatan perhatian siswa serta kurangnya media yang mendukung proses pembelajaran fisika. Kondisi ini penulis temukan juga ketika melaksanakan proses belajar mengajar. Tidak semua peserta didik menaruh perhatian dan keinginan untuk mempelajari mata pelajaran Fisika .

Menurut tes DISA tahun 2003 menunjukan siswa SMP Indonesia menduduki peringkat ke 38 dari 41 negara dalam pengetahuan sainsnya ( Defense Information System Agency, 2010 ). Salah satu pelajaran formal yang dipelajari di sekolah adalah fisika. Fisika sebagai salah satu bidang studi yang diikutsertakan dalam ujian nasional yang mengharuskan siswa memperoleh nilai 5,50 sebagai standar minimum kelulusan yang ditetapkan oleh pemerintah. Tentu saja siswa diharapkan memperoleh nilai diatas standar 
kelulusan (5,50) siswa akan mendapatkan peringkat prestasi di kelas dan di sekolah serta dapat melanjutkan pendidikan kejenjang yang lebih tinggi melalui salah satu bidang studi yaitu fisika.

Berdasarkan hasil studi pendahuluan yang diperoleh penulis di MTsN 3 Medan yang dilaksanakan melalui wawancara guru dan siswa. Hasil wawancara dengan guru bidang studi IPA fisika Bapak Drs. Irhamsyah (2012) diketahui bahwa nilai ulangan harian siswa kelas IX tahun pelajaran 2011-2012 masih rendah, begitu juga dengan nilai ujian semester yang diperoleh siswa yang masih dibawah KKM yaitu 75, hanya sedikit siswa yang memperoleh nilai yang baik. Rata- rata nilai ujian semester siswa yang hanya 68 . Rendahnya hasil belajar fisika siswa disebabkan oleh kebiasaan belajar siswa yang hanya memusatkan pada perhatian guru, siswa tidak serius dalam belajar dan serta banyak bermain dikarenakan kurangnya keberadaan dan pemanfaatan multimedia dalam pembelajaran fisika.

Berdasarkan hasil wawancara kepada beberapa siswa yang dilakukan pada november 2011 diketahui bahwa para siswa menganggap pelajaran fisika merupakan mata pelajaran yang sulit, tidak menarik dan membosankan dikarenakan kurangnya media yang mendukung pembelajaran fisika yang membantu pemahaman siswa. Oleh karena itu, diperlukan suatu sasaran yang tepat untuk mengatasi masalah-masalah yang ada dalam pembelajaran IPA Terpadu khususnya fisika. Sasaran yang dimaksud disini adalah penggunaan media pembelajaran IPA Terpadu dalam pembelajaran interaktif. Zaifbio (2009), strategi pembelajaran interaktif menekankan pada diskusi dan sharing di antara peserta didik. Diskusi dan sharing memberi kesempatan peserta didik untuk bereaksi terhadap gagasan, pengalaman, pendekatan dan pengetahuan guru atau temannya dan untuk membangun cara alternatif untuk berfikir dan merasakan. Kelebihan strategi ini antara lain: (1) peserta didik dapat belajar dari temannya dan guru untuk membangun keterampilan sosial dan kemampuan-kemampuan, mengorganisasikan pemikiran dan membangun argumen yang rasional. Strategi pembelajaran interaktif memungkinkan untuk menjangkau kelompok-kelompok

dan metode-metode interaktif. Kekurangan dari strategi ini sangat bergantung pada kecakapan guru dalam menyusun dan mengembangkan dinamika kelompok.

Kehadiran media sangat dibutuhkan dalam pembelajaran sebagaimana yang dikemukakan oleh para peneliti sebelumnya. Kristianto (2010), era perkembangan teknologi informasi yang semakin meningkat, khususnya dalam teknologi komputer sangat berpengaruh dan berperan penting dalam dunia pendidikan. Terutama dalam media pembelajaran, yaitu sering disebut dengan komputer pembelajaran atau Computer Assisted Instructional (CAI). Pengunaan media tersebut sangat membantu sekali dalam proses belajar siswa secara mandiri. Aplikasi program yang disajikan meliputi teks, grafis, animasi, video, dan sound. Apliaksi program tersebut dapat menarik perhatian dalam proses belajar mengajar.

Kehadiran media pembelajaran interaktif dalam proses belajar mengajar telah membuat suasana yang berbeda dalam kelas, karena materi yang dulunya diajarkan dengan ceramah dan hanya monoton dapat divariasi dengan menampilkan tayangan berupa integrasi teks, suara, gambar bergerak dan video. Hal ini tentunya akan membuat siswa menjadi tertarik dengan materi yang diajarkan. Sujito (2008), dalam uji coba lapangan media interaktif terbukti mampu meningkatkan antusiasme siswa untuk terus belajar". Hal ini diperkuat oleh pendapat Kristiningrum (2007), multimedia yang dibuat bermanfaat untuk meningkatkan motivasi belajar siswa melalui pengembangan dan penciptaan sarana belajar, sumber belajar, serta menunjukkan kemajuan teknologi yang semakin pesat. CD Pembelajaran yang dihasilkan dapat dijadikan sebagai variasi sarana pembelajaran dan meningkatkan kreativitas serta memotivasi siswa untuk terus belajar supaya dapat memenuhi tuntutan perkembangan zaman.

Dalam memilih media yang paling tepat, Dick \& Carey (2005) faktor penting dalam pemilihan media pembelajaran, yaitu: (1) ketersediaan media di lingkungan pembelajaran, (2) kesanggupan ahli memproduksi materi pembelajaran untuk digunakan dengan media yang dipilih, (3) fleksibilitas, waktu, dan kecocokan materi dengan media, dan (4) faktor biaya. Disamping kesesuaian dengan perilaku belajarnya, faktor lain yang harus dipertimbangkan dalam pemilihan media yaitu faktor yang menyangkut keluwesan, kepraktisan dan ketahanan media yang bersangkutan untuk waktu yang lama. Selain itu faktor efektivitas harus tetap 
diperhatikan sebab faktor efektivitas ini berpengaruh terhadap biaya pemakaian dalam jangka waktu yang panjang. Dengan demikian media memiliki fungsi yang jelas yaitu memperjelas, memudahkan dan membuat menarik pesan kurikulum yang akan disampaikan oleh guru kepada peserta didik sehingga dapat memotivasi belajar dan mengefisiensikan proses belajar. Sagala (2003) Pembelajaran interaktif mempunyai dua karakteristik yaitu: (1) dalam proses pembelajaran melibatkan proses mental siswa secara maksimal, bukan hanya menuntut siswa sekedar mencatat, akan tetapi menghendaki aktivitas siswa dalam proses berpikir; (2) dalam pembelajaran membangun suasana dialogis dan proses tanya jawab terus menerus yang diarahkan untuk memperbaiki dan meningkatkan kemampuan siswa untuk memperoleh pengetahuan yang mereka konstruksi sendiri.

Mengacu pada pendapat ahli dapat disimpulkan bahwa pengembangan media pembelajaran interaktif pada mata pelajaran fisika merupakan upaya pemecahan masalah pembelajaran fisika dengan teknologi komputer yang berkembang semakin canggih melalui serangkaian proses desain, produksi, dan evaluasi. Kegiatannya bukan hanya mengembangkan produk pembelajaran fisika secara terpisah tetapi menyangkut mendesain pembelajarannya, dan pemanfaatannya. Media pembelajaran interaktif akan menghasilkan penguatan yang tinggi. Salah satu alat bantu untuk mengembangkan media pembelajaran interaktif adalah dengan Software Macromedia Flash.

Untuk menghasilkan produk media pembelajaran interaktif diperlukan perencanaan dan perancangan pembelajaran yang baik. Dalam pengembangan media pembelajaran interaktif ini digunakan rancangan pembelajaran model Dick \& carey (2005). Model Dick \& Carey (2005) adalah salah satu dari model prosedural, yaitu model yang menyarankan agar penerapan prinsip desain instruksional disesuaikan dengan langkahlangkah yang harus di tempuh secara berurutan. Model Dick \& Carey (2005) Perancangan Instruksional menurut sistem pendekatan model Dick \& Carey terdapat beberapa komponen yang akan dilewati di dalam proses pengembangan dan perencanaan tersebut.

Heinich (1996) tahap perencanaan awal dimulai dengan adanya ide atau gagasan untuk menghasilkan suatu produk. Identifikasi kebutuhan merupakan tahap pertama karena mengembangkan materi pembelajaran baru lebih sulit dan mahal sehingga perlu pertimbangan masak-masak karena terlalu besar risikonya memproduksi suatu program yang belum tentu diminati. Identifikasi pertama dilakukan terhadap (1) tujuan, untuk mengetahui apa yang akan dicapai peserta didik setelah belajar, (2) karakteristik peserta didik, untuk mengetahui apakah mereka memiliki prasyarat pengetahuan dan kemampuan menggunakan media pembelajaran interaktif yang dihasilkan, (3) dana, apakah cukup dana untuk mengadakan program tersebut , (4) keahlian teknis, apakah telah memiliki keahlian untuk mengembangkan media pembelajaran tersebut, dan (5) fasilitas dan peralatan, tersediakah fasilitas dan peralatan untuk menghasilkan dan menggunakan media pembelajaran tersebut. Identitas yang kedua adalah terhadap kurikulum, untuk menentukan materi mana yang akan dituangkan dalam media pembelajaran.

Penelitian dan pengembangan ini bertujuan untuk: (1) menghasilkan media pembelajaran interaktif macromedia flash pada mata pelajaran fisika yang layak digunakan, mudah dipelajari; (2) mengetahui hasil pelaksanaan pembelajaran dengan menggunakan media pembelajaran interaktif macromedia flash pada mata pelajaran fisika; dan (3) mengetahui keunggulan media pembelajaran interaktif macromedia flash jika dibandingkan dengan power point yang dikembangkan pada mata pelajaran fisika.

\section{METODE PENELITIAN}

Penelitian ini dilaksanakan di MTsN 3 Medan pada siswa kelas IX semester genap. Model pengembangan yang digunakan dalam pengembangan media pembelajaran ini adalah model pengembangan Borg \& Gall (2005) yang dipadu dengan model pengembangan pembelajaran model Dick \& Carey (2005). Prosedur pengembangan yang ditempuh untuk menghasilkan produk media pembelajaran interaktif dibagi menjadi 5 tahap, yaitu: (1) tahap pertama melakukan penelitian pendahuluan, (2) tahap kedua pembuatan desain software, (3) tahap ketiga pengumpulan bahan, (4) tahap keempat membuat dan memproduksi media pembelajaran interaktif, dan (5) tahap kelima yaitu review atau uji lapangan dalam rangka evaluasi formatif dan revisi produk. 
Uji coba produk awal dalam pengembangan ini dilaksanakan dengan melalui beberapa langkah sebagai berikut :

1) Langkah pertama menentukan sasaran uji coba yaitu ahli rancangan pembelajaran, ahli materi, ahli media, dan peserta didik. Masukan yang diharapkan dari para ahli masing-masing adalah kesesuaian uraian materi dengan standart kompetensi dan kompetensi dasar, keakuratan materi, dan materi pendukung pembelajaran. Kemudian menganalisis konseptual serta revisi pengembangan tahap I.

2) Langkah kedua uji coba perorangan ( uji satu- satu ). Pada langkah ini produk telah diperbaiki pada revisi I (langkah 1) dan angket penilaian diberikan pada pemakai secara perorangan dan yang tujuannya untuk mengetahui kesahihan produk setelah diperbaiki berdasarkan tinjauan yang terdiri dari 3 siswa. Masukan-masukan dari uji coba II ini selanjutnya dipakai sebagai dasar dalam melakukan perbaikanperbaikan terhadap produk (revisi II).

3) Langkah ketiga uji kelompok kecil. Uji coba ini dilakukan untuk mengetahui apakah masih terdapat kekurangankekurangan yang perlu diperbaiki dari produk yang dikembangkan setelah diskusi baik berdasarkan tinjauan ahli maupun pada uji coba perorangan. Jika masih terdapat kekurangannya maka berdasarkan masukan yang diperoleh akan dilakukan perbaikan III (revisi III).

4) Langkah keempat uji coba lapangan. Uji coba ini dilakukan untuk mengetahui apakah masih terdapat kekurangankekurangan yang perlu diperbaiki dari produk yang dikembangkan setelah diskusi baik berdasarkan tinjauan ahli maupun pada uji coba perorangan dan kelompok kecil. Jika masih terdapat kekurangannya maka berdasarkan masukan yang diperoleh akan dilakukan perbaikan IV (revisi IV).
Jika tidak, maka produk dapat dinyatakan layak sebagai sumber belajar sahih di lapangan.

Analisis data dalam penelitian ini menggunakan analisis deskriptif kuantitatif. Semua data yang terkumpul dianalisis dengan teknik statistik deskriptif yang secara kuantitatif dipisahkan menurut kategori untuk mempertajam penilaian dalam menarik kesimpulan. Data kualitatif yang berupa pernyataan sangat kurang baik, kurang baik, sdang, baik dan sangat baik diubah menjadi data kuantitatif dengan skala nilai 1 sampai 5 . Hasilnya dirata-ratakan dan digunakan untuk menilai kualitas media pembelajaran interaktif. Teknik pengumpulan data pada penelitian pengembangan ini adalah angket yang disebar ke beberapa validator, soal latihan pre-test dan post-test. Untuk meyakinkan standar kelayakan dan keefektifan produk dilakukan pengujian keefektifan produk yang dikembangkan dan uji t. Analisis data pada penelitian ini menggunakan tehnik analisis kuantitatif.

\section{HASIL DAN PEMBAHASAN \\ Hasil}

Uji coba perorangan dilakukan pada 3 orang siswa kelas $\mathrm{X}$ yang terdiri dari 1 siswa yang memiliki prestasi tinggi, 1 orang berprestasi sedang dan 1 orang berprestasi rendah. Tujuan dari uji coba perorangan ini adalah untuk mengidentifikasi kekurangan produk pembelajaran setelah ditinjau ulang oleh tenaga ahli. Penilaian dan masukan dari uji coba ini adalah tentang penyajian produk pembelajaran meliputi aspek kualitas materi pembelajaran dan aspek kualitas teknis/tampilan yang terdapat dalam media pembelajaran interaktif mata pelajaran Fisika.

Hasil uji coba berupa skor penilaian terhadap media pembelajaran interaktif pada mata pelajaran Fisika pada uji coba perorangan dapat dilihat pada tabel berikut 1 .

Tabel 1. Skor Penilaian Media Pembelajaran Interaktif Mata Pelajaran Fisika Pada Uji Coba Perorangan Tentang Kualitas Materi Pembelajaran

\begin{tabular}{|l|l|c|c|c|c|c|c|}
\hline \multirow{2}{*}{ No } & \multicolumn{1}{|c|}{ Indikator Penilaian } & \multicolumn{3}{|c|}{ Responden } & Jumlah & \multirow{2}{*}{ Rata-rata } & Kriteria \\
\cline { 2 - 5 } & \multicolumn{1}{|c|}{1} & 2 & 3 & Skor & & \\
\hline 1 & Kesesuaian materi & 4 & 4 & 4 & 12 & $80,00 \%$ & Baik \\
\hline 2 & Kejelasan petunjuk belajar & 4 & 5 & 5 & 14 & $93,33 \%$ & Sangat Baik \\
\hline 3 & $\begin{array}{l}\text { Kemudahan memahami kalimat } \\
\text { pada teks }\end{array}$ & 4 & 5 & 5 & 14 & $93,33 \%$ & Sangat Baik \\
\hline 4 & $\begin{array}{l}\text { Kemudahan memahami } \\
\text { pembelajaran }\end{array}$ & 5 & 5 & 4 & 14 & $93,33 \%$ & Sangat Baik \\
\hline
\end{tabular}




\begin{tabular}{|c|c|c|c|c|c|c|c|}
\hline \multirow{2}{*}{ No } & \multirow{2}{*}{ Indikator Penilaian } & \multicolumn{3}{|c|}{ Responden } & \multirow{2}{*}{$\begin{array}{c}\text { Jumlah } \\
\text { Skor }\end{array}$} & \multirow{2}{*}{ Rata-rata } & \multirow{2}{*}{ Kriteria } \\
\hline & & 1 & 2 & 3 & & & \\
\hline 5 & Ketepatan urutan penyajian & 4 & 5 & 4 & 13 & $86,67 \%$ & Sangat Baik \\
\hline 6 & Kecukupan latihan & 5 & 4 & 5 & 14 & $93,33 \%$ & Sangat Baik \\
\hline 7 & Kejelasan umpan balik & 4 & 4 & 4 & 12 & $80,00 \%$ & Baik \\
\hline 8 & Bantuan belajar dengan program & 5 & 5 & 5 & 15 & $100,00 \%$ & Sangat Baik \\
\hline & Rata-rata & & & & 9,00 & $90,00 \%$ & Sangat Baik \\
\hline
\end{tabular}

Tabel 1 menunjukkan tanggapan 3 siswa pada uji coba perorangan terhadap media pembelajaran interaktif mata pelajaran Fisika. Ada enam butir yang termasuk katagori "Sangat Baik" yaitu kejelasan petunjuk belajar, kemudahan memahami kalimat pada teks, kemudahan memahami pembelajaran, ketepatan urutan penyajian, kecukupan latihan dan bantuan belajar dengan program. Sedangkan kesesuaian materi dan kejelasan umpan balik dinilai "Baik". Secara keseluruhan dari aspek kualitas materi pembelajaran dinilai "Sangat Baik".

Penilaian siswa pada media pembelajaran interaktif tentang aspek kualitas teknis/tampilan dapat dilihat pada tabel 2.

Tabel 2. Skor Penilaian Media Pembelajaran Interaktif Mata Pelajaran Fisika Pada Uji Coba Perorangan Tentang Aspek Kualitas Teknis/Tampilan

\begin{tabular}{|l|l|c|c|c|c|c|c|}
\hline \multirow{2}{*}{ No } & \multirow{2}{*}{ Indikator Penilaian } & \multicolumn{3}{|c|}{ Responden } & \multirow{2}{*}{ Jumlah } & \multirow{2}{*}{ Rata-rata } & \multirow{2}{*}{ Kriteria } \\
\cline { 3 - 5 } & & 1 & 2 & 3 & Skor & & \\
\hline 1 & Keindahan Tampilan layar & 5 & 5 & 5 & 15 & $100,00 \%$ & Sangat Baik \\
\hline 2 & Keterbacaan teks & 4 & 5 & 5 & 14 & $93,33 \%$ & Sangat Baik \\
\hline 3 & Kualitas gambar dan animasi & 5 & 5 & 5 & 15 & $100,00 \%$ & Sangat Baik \\
\hline 4 & Komposisi warna & 5 & 5 & 5 & 15 & $100,00 \%$ & Sangat Baik \\
\hline 5 & Navigasi & 4 & 5 & 5 & 14 & $93,33 \%$ & Sangat Baik \\
\hline 6 & Daya dukung musik & 5 & 5 & 4 & 14 & $93,33 \%$ & Sangat Baik \\
\hline 7 & Interaksi & 5 & 4 & 5 & 14 & $93,33 \%$ & Sangat Baik \\
\hline & Rata-rata & & & & $\mathbf{9 , 6 2}$ & $\mathbf{9 6 , 2 0} \%$ & Sangat Baik \\
\hline
\end{tabular}

Tanggapan siswa pada uji coba perorangan yang ditunjukkan pada Tabel 2 dijelaskan bahwa media pembelajaran interaktif dari aspek kualitas teknis/ tampilan secara keseluruhan dinilai "Sangat Baik". Terdapat tujuh butir aspek yang dinilai "Sangat Baik" yaitu keindahan tampilan layar, keterbacaan teks, kualitas gambar dan animasi, komposisi warna, navigasi, daya dukung musik dan interaksi.

Uji coba kelompok kecil masing-masing dilakukan terhadap 9 orang dengan 3 orang yang kemampuan kurang, kemampuan sedang, dan pandai. Data uji coba kelompok kecil ini dimaksudkan untuk mengetahui beberapa kelemahan atau hambatan yang dihadapi ketika produk media pembelajaran interaktif mata pelajaran Fisika tersebut digunakan. Uji coba kelompok kecil ini digunakan sebagai pengalaman awal sebelum produk diujicobakan ke lapangan. Hasil evaluasi terhadap media pembelajaran interaktif mata pelajaran Fisika pada aspek kualitas materi pembelajaran dapat dilihat pada Tabel 3.

Tabel 3. Skor Penilaian Media Pembelajaran Interaktif Mata Pelajaran Fisika Uji Coba Kelompok Kecil Pada Aspek Kualitas Materi pembelajaran

\begin{tabular}{|r|l|c|c|c|c|c|c|c|}
\hline \multirow{2}{*}{ No } & \multicolumn{1}{|c|}{ Indikator Penilaian } & \multicolumn{5}{|c|}{ Skor } & \multirow{2}{*}{ Rata-rata } & \multirow{2}{*}{ Kriteria } \\
\cline { 3 - 7 } & & 1 & 2 & 3 & 4 & 5 & $97,78 \%$ & Sangat Baik \\
\hline 1 & Kesesuaian materi & & & & 1 & 8 & $97,78 \%$ & Sangat Baik \\
\hline 2 & Kejelasan petunjuk belajar & & & & 1 & 8 & $97,78 \%$ & Sangat Baik \\
\hline 3 & $\begin{array}{l}\text { Kemudahan memahami kalimat pada } \\
\text { teks }\end{array}$ & & & 1 & 8 & 97,700 & Sangat Baik \\
\hline 4 & Kemudahan memahami pembelajaran & & & & & 9 & $100,00 \%$ & Sangat Baik \\
\hline 5 & Ketepatan urutan penyajian & & & & 1 & 8 & $97,78 \%$ & \\
\hline
\end{tabular}




\begin{tabular}{|r|l|c|c|c|c|c|c|c|}
\hline \multirow{2}{*}{ No } & \multicolumn{1}{|c|}{ Indikator Penilaian } & \multicolumn{5}{c|}{ Skor } & \multirow{2}{*}{ Rata-rata } & \multirow{2}{*}{ Kriteria } \\
\cline { 3 - 8 } & & 1 & 2 & 3 & 4 & 5 & & \\
\hline 6 & Kecukupan latihan & & & & 2 & 7 & $95,56 \%$ & Sangat baik \\
\hline 7 & Kejelasan umpan balik & & & & 3 & 6 & $93,33 \%$ & Sangat Baik \\
\hline 8 & Bantuan belajar dengan program & & & & 1 & 8 & $97,78 \%$ & Sangat Baik \\
\hline & Rata-rata & & & & & & $\mathbf{9 7 , 2 2} \%$ & Sangat Baik \\
\hline
\end{tabular}

Penilaian pada aspek kualitas materi pembelajaran untuk uji coba kelompok kecil yang tampak pada Tabel 3 menunjukkan bahwa secara keseluruhan dalam kriteria "Sangat Baik", yaitu pada kesesuaian materi, kejelasan petunjuk belajar, kemudahan memahami pembelajaran, ketepatan urutan penyajian, kecukupan latihan, kejelasan umpan balik dan bantuan belajar dengan program.

Hasil evaluasi terhadap media pembelajaran interaktif mata pelajaran Fisika pada aspek kualitas teknis/tampilan dapat dilihat pada Tabel 4. Penilaian pada aspek kualitas teknis/tampilan untuk uji coba kelompok kecil yang tampak pada Tabel 4 menunjukkan bahwa secara keseluruhan dalam kriteria "Sangat Baik", terdapat tujuh aspek yang dinilai "Sangat Baik" yaitu keindahan tampilan layar, keterbacaan teks, kualitas gambar dan animasi, komposisi warna, navigasi, daya dukung musik dan interaksi.

Tabel 4. Skor Penilaian Media Pembelajaran Interaktif Mata Pelajaran Fisika Uji Coba Kelompok Kecil Pada Aspek Kualitas Teknis/Tampilan

\begin{tabular}{|r|l|c|c|c|c|c|c|c|}
\hline \multirow{2}{*}{ No Indikator Penilaian } & \multicolumn{5}{|c|}{ Rkor } & \multirow{2}{*}{ Rata-rata } & \multirow{2}{*}{ Kriteria } \\
\cline { 3 - 7 } & & 1 & 2 & 3 & 4 & 5 & & \\
\hline 1 & Keindahan tampilan layar & & & & 2 & 7 & $95,56 \%$ & Sangat Baik \\
\hline 2 & Keterbacaan teks & & & & 1 & 8 & $97,78 \%$ & Sangat Baik \\
\hline 3 & Kualitas gambar dan animasi & & & & 1 & 8 & $97,78 \%$ & Sangat Baik \\
\hline 4 & Komposisi warna & & & & 3 & 6 & $93,33 \%$ & Sangat Baik \\
\hline 5 & Navigasi & & & & 1 & 8 & $97,78 \%$ & Sangat Baik \\
\hline 6 & Daya dukung musik & & & & 3 & 6 & $93,33 \%$ & Sangat baik \\
\hline 7 & Interaksi & & & & & 9 & $100,00 \%$ & Sangat Baik \\
\hline & Rata-rata & & & & & & $\mathbf{9 6 , 3 4 \%}$ & Sangat Baik \\
\hline
\end{tabular}

Uji coba lapangan dilakukan terhadap kelas IX-D yang teridiri dari 40 siswa dan penentuan kelas uji coba ini dilakukan secara acak dari 5 kelas IX yang ada. Uji coba lapangan menghasilkan data-data yang nantinya akan mengukur kelayakan dari produk yang dikembangkan, serta untuk mengetahui bagaimana manfaat produk tersebut bagi pemakainya. Hasil evaluasi terhadap paket pembelajaran pada aspek kualitas materi pembelajaran dapat dilihat pada tabel pada Tabel 5.

Tabel 5 menunjukkan hasil tanggapan peserta didik pada aspek kualitas materi pembelajaran untuk uji coba lapangan dan keseluruhannya dalam kriteria "Sangat Baik".

Tabel 5. Skor Penilaian Media Pembelajaran Interaktif Mata Pelajaran Fisika Uji Coba Lapangan Pada Aspek Kualitas Materi Pembelajaran

\begin{tabular}{|l|l|l|l|l|l|l|l|l|}
\hline \multirow{2}{*}{ No } & \multirow{2}{*}{ Indikator Penilaian } & \multicolumn{5}{|c|}{ Skor } & \multirow{2}{*}{ Rata-rata } & \multirow{2}{*}{ Kriteria } \\
\cline { 3 - 8 } & 1 & 2 & 3 & 4 & 5 & & \\
\hline 1 & Kesesuaian materi & & & & 10 & 30 & $88,24 \%$ & Sangat Baik \\
\hline 2 & Kejelasan petunjuk belajar & & & & & 40 & $100,00 \%$ & Sangat Baik \\
\hline 3 & $\begin{array}{l}\text { Kemudahan memahami kalimat } \\
\text { pada teks }\end{array}$ & & & & 5 & 35 & $94,18 \%$ & Sangat Baik \\
\hline 4 & $\begin{array}{l}\text { Kemudahan memahami } \\
\text { pembelajaran }\end{array}$ & & & & 5 & 35 & $94,18 \%$ & Sangat Baik \\
\hline 5 & Ketepatan urutan penyajian & & & & 1 & 33 & $97,06 \%$ & Sangat Baik \\
\hline 6 & Kecukupan latihan & & & & 4 & 30 & $88,24 \%$ & Sangat Baik \\
\hline
\end{tabular}




\begin{tabular}{|l|l|l|l|l|l|l|l|l|}
\hline \multirow{2}{*}{ No } & \multirow{2}{*}{ Indikator Penilaian } & \multicolumn{5}{|c|}{ Skor } & \multirow{2}{*}{ Rata-rata } & \multirow{2}{*}{ Kriteria } \\
\cline { 2 - 8 } & & 1 & 2 & 3 & 4 & 5 & & \\
\hline 7 & Kejelasan umpan balik & & & & 1 & 33 & $97,06 \%$ & Sangat Baik \\
\hline 8 & Bantuan belajar dengan program & & & & & 34 & $100,00 \%$ & Sangat Baik \\
\hline Rata-rata & & & & & & $\mathbf{9 4 , 8 7 \%}$ & Sangat Baik \\
\hline
\end{tabular}

Hasil evaluasi terhadap paket peserta didik pada aspek kualitas pembelajaran pada aspek kualitas teknis/tampilan untuk uji coba lapangan dan teknis/tampilan dapat dilihat pada tabel pada keseluruhannya dalam kriteria "Sangat Baik".

Tabel 6. Tabel 6 menunjukkan hasil tanggapan

Tabel 6. Skor Penilaian Media Pembelajaran Interaktif Mata Pelajaran Fisika Uji Coba Lapangan Pada Aspek Kualitas Teknis/Tampilan

\begin{tabular}{|l|l|l|l|l|l|l|l|l|}
\hline \multirow{2}{*}{ No } & \multirow{2}{*}{ Indikator Penilaian } & \multicolumn{5}{|c|}{ Skor } & \multirow{2}{*}{ Rata-rata } & \multirow{2}{*}{ Kriteria } \\
\cline { 4 - 8 } & & 1 & 2 & 3 & 4 & 5 & & \\
\hline 1 & Keindahan tampilan layar & & & & 2 & 32 & $94,12 \%$ & Sangat Baik \\
\hline 2 & Keterbacaan teks & & & & 1 & 33 & $97,06 \%$ & Sangat Baik \\
\hline 3 & Kualitas gambar dan animasi & & & & & 34 & $100,00 \%$ & Sangat Baik \\
\hline 4 & Komposisi warna & & & & 2 & 32 & $94,12 \%$ & Sangat Baik \\
\hline 5 & Navigasi & & & & 3 & 31 & $91,18 \%$ & Sangat Baik \\
\hline 6 & Daya dukung musik & & & & 4 & 30 & $88,24 \%$ & Sangat Baik \\
\hline 7 & Interaksi & & & & & 34 & $100,00 \%$ & Sangat Baik \\
\hline \multicolumn{2}{|c|}{ Rata-rata } & & & & & & $\mathbf{9 4 , 9 6 \%}$ & Sangat Baik \\
\hline
\end{tabular}

\section{Deskripsi Data Penelitian}

Hal pertama yang dilakukan terhadap kedua kelas sample sebelum memberikan perlakuan yang berbeda adalah memberikan tes awal untuk mengetahui kemampuan awal masing-masing siswa kedua kelas. Selanjutnya dilakukan pembelajaran yang berbeda yaitu kelas eksperimen dengan media pembelajaran interaktif dan kelas control dengan media pembelajaran powerpoint. Kemudian pada akhir proses pembelajaran akan diberikan tes akhir untuk mengetahui hasil belajar siswa. Berdasarkan hasil penelitian maka diperoleh hasil test awal (pretest) dan test akhir (post test) untuk kedua kelompok sampel yaitu kelompok eksperimen dan control (lampiran). Setelah itu, dilakukan perhitungan sehingga diperoleh ratarata pretes, postes, dan simpangan baku seperti pada tabel 7 di bawah ini.

Tabel 7. Rata-rata dan Simpangan Baku

\begin{tabular}{|c|c|c|c|c|c|c|c|}
\hline \multicolumn{4}{|c|}{ Kelas Eksperimen } & \multicolumn{4}{c|}{ Kelas Kontrol } \\
\hline \multicolumn{2}{|c|}{ Pretes } & \multicolumn{2}{c|}{ Post Test } & \multicolumn{3}{c|}{ Pretest } & \multicolumn{2}{c|}{ Post Test } \\
\hline$\overline{\mathrm{X}}$ & $\mathrm{S}$ & $\overline{\mathrm{X}}$ & $\mathrm{S}$ & $\overline{\mathrm{X}}$ & $\mathrm{S}$ & $\overline{\mathrm{X}}$ & $\mathrm{S}$ \\
\hline 63,88 & 12,58 & 86,13 & 6,55 & 64,00 & 12,34 & 71,00 & 10,48 \\
\hline
\end{tabular}

Berdasarkan tabel 43 diperoleh rata-rata nilai pretes kelas eksperimen sebesar 63,88 dengan nilai tertinggi 85 dan nilai terendah 45 serta simpangan baku 12,58 sedangkan untuk rata-rata nilai postes sebesar 86,13 dengan nilai tertinggi 95 dan nilai terendah 70 serta simpangan baku 6,55.

Rata-rata nilai pretes kelas kontrol sebesar 64,00 dengan nilai tertinggi 85 dan nilai terendah 40 serta simpangan baku 12,34 sedangkan untuk rata-rata nilai postes sebesar
71,00 dengan nilai tertinggi 85 dan nilai terendah 55 serta simpangan baku 10,48.

Uji hipotesis dengan menggunakan uji statistik uji t dua pihak. Uji ini dilakukan untuk mengetahui apakah hipotesis dalam penelitian ini diterima atau ditolak. Kriteria pengujian jika $-\mathrm{t}_{\text {tabel }} \leq \mathrm{t}_{\text {hitung }} \leq \mathrm{t}_{\text {tabel }}$ maka hipotesis alternatif (Ha) ditolak dan hipotesis nihil (Ho) diterima. Data hasil uji hipotesis seperti pada tabel 8 dibawah ini: 
Tabel 8. Hasil Uji Hipotesis

\begin{tabular}{|c|c|c|c|}
\hline Data & $\mathrm{t}_{\text {hitung }}$ & $\mathrm{t}_{\text {tabel }}$ & Keterangan \\
\hline Hasil Belajar & 7,73 & 1,994 & (Ha) diterima, (Ho) ditolak \\
\hline
\end{tabular}

Dari data distribusi $\mathrm{t}$ diperoleh $\mathrm{t}$ tabel $=$ 1,994. Berdasarkan kriteria pengujian hipotesis, jika $-\mathrm{t}_{\text {tabel }} \leq \mathrm{t}_{\text {hitung }} \leq \mathrm{t}_{\text {tabel }}$, maka $\mathrm{H}_{0}$ diterima, $\mathrm{H}_{\mathrm{a}}$ ditolak. Tetapi berdasarkan perhitungan diperoleh $\mathrm{t}$ hitung $=7,73$ sehingga harga $\mathrm{t}_{\text {tabel }}<\mathrm{t}_{\text {hitung }}>\mathrm{t}_{\text {tabel }}(-1,994<7,73>1,994)$ dengan taraf signifikan $0,05 \quad(\alpha=0,05)$. Dengan demikian kriteria pengujian hipotesis $\mathrm{t}_{\text {tabel }} \leq \mathrm{t}_{\text {hitung }} \leq \mathrm{t}_{\text {tabel }}$ tidak terpenuhi. Artinya $\mathrm{H}_{0}$ ditolak, Ha diterima"Terdapat perbedaan hasil belajar fisika siswa yang signifikan antara pembelajaran yang menggunakan media interaktif dengan pembelajaran dengan media powerpoint.

\section{Pembahasan}

Produk pengembangan media pembelajaran interaktif pada mata pelajaran Fisika merupakan materi pembelajaran Fisika yang telah dikembangkan dengan memperhatikan aspek pembelajaran dan media sebagai prinsip desain pesan pembelajaran. Penelitan pengembangan produk yang dilakukan ini diarahkan untuk menghasilkan suatu produk berupa media pembelajaran interaktif mata pelajaran Fisika untuk peserta didik MTS kelas IX yang digunakan untuk meningkatkan proses pembelajaran maupun kompetensi peserta didik. Karena itu dalam prosesnya penelitian ini dilakukan dengan diawali studi pendahuluan, kemudian mendesain media pembelajaran, melakukan validasi produk dan melakukan revisi dan penyempurnaan berdasarkan analisis data validasi dari ahli materi, ahli desain pembelajaran dan ahli rekayasa perangkat lunak yang dilanjutkan dengan uji coba perorangan, uji coba kelompok kecil, dan uji coba lapangan sehingga dihasilkan media pembelajaran yang layak digunakan sesuai dengan karakteristik bidang studi dan siswa sebagai pengguna.

Aspek yang direvisi dan disempurnakan berdasarkan analisis data dan uji coba serta masukan dari ahli materi, ahli desain pembelajaran, ahli rekayasa perangkat lunak dan peserta didik selaku pengguna media pembelajaran interaktif ini, bertujuan untuk menggali beberapa aspek yang lazim dalam proses pengembangan suatu produk. Variabelvariabel media pembelajaran memiliki nilai rata-rata sangat baik. Adapun variabel media pembelajaran yang dinilai meliputi kelayakan isi, penyajian, kebahasaan, pemprograman, dan kegrafikan.

Manfaat yang diperoleh dari penggunaan media pembelajaran interaktif adalah konsep yang disajikan mudah dipelajari, dipahami dan sistematis. Media pembelajaran interaktif memberi kesempatan pada peserta didik untuk belajar sesuai dengan kecepatan masing-masing, belajar lebih cepat dan tidak menimbulkan kebosanan karena dilengkapi dengan gambar-gambar dan animasi serta soal latihan yang bervariasi. Adanya pengulangan yang harus dilakukan saat jawaban salah menjadikan peserta didik lebih memahami materi. Media pembelajaran interaktif ini juga dapat digunakan sebagai alternatif media pembelajaran secara klasikal maupun individual.

Dari hasil pengolahan data penelitian yang dilakukan, terdapat perbedaan hasil belajar Fisika antara siswa yang dibelajarkan dengan menggunakan media pembelajaran interaktif dan siswa yang dibelajarkan dengan menggunakan media powerpoint yaitu rata-rata hasil belajar Fisika siswa yang dibelajarkan dengan menggunakan media pembelajaran interaktif lebih tinggi dibandingkan dengan siswa yang dibelajarkan dengan menggunakan media powerpoint. Hal ini dapat dilihat dari hasil nilai rata-rata Fisika siswa yang yang diajar dengan media pembelajaran interaktif yaitu sebesar $86,13 \%$, sedangkan hasil nilai rata-rata Fisika siswa yang yang diajar dengan media powerpoint sebesar 71,00\%. Dari data ini membuktikan bahwa penggunaan media pembelajaran interaktif lebih baik dalam meningkatkan pengetahuan siswa dalam pembelajaran Fisika daripada penggunaan media powerpoint.

Siswa dapat mengerjakan soal-soal latihan yang telah dilengkapi dengan balikan dan pembahasan sehingga siswa dapat mengetahui kesalahan yang telah dilakukan dalam mengerjakan soal latihan tersebut. Media pembelajaran interaktif juga dilengkapi dengan rangkuman yang dapat membantu siswa memperoleh ringkasan materi pelajaran yang dipaparkan. 
Pembelajaran dengan media interaktif juga memungkinkan guru bebas melakukan interaksi dengan siswa sehingga pembelajaran tersebut bersifat interaktif yang membuat pembelajaran terfokus pada informasi yang sedang dipelajari. Hal ini berbeda dengan pembelajaran menggunakan media powerpoint, siswa tidak berinteraksi langsung pada sumber informasi dan pembelajaran didominasi oleh guru yang menyajikan informasi secara linier atau satu arah. Hal ini terjadi karena siswa mendapatkan sumber informasi hanya dari guru dan materi-materi yang ada pada interaktif tanpa bisa memperoleh balikan dari soal-soal latihan yang dikerjakan. Pembelajaran dengan menggunakan media pembelajaran interaktif menempatkan guru menggunakan kontrol pembelajaran dengan aktif, sementara siswa relatif pasif menerima dan mengikuti apa yang disampaikan guru. Guru menyampaikan materi secara terstruktur dengan harapan materi pelajaran yang disampaikan dapat dikuasai dengan baik dengan terfokus kepada kemampuan akademik.

Walaupun dalam penelitian diperoleh data bahwa hasil belajar Fisika siswa lebih tinggi jika dibelajarkan dengan media pembelajaran interaktif daripada hasil belajar Fisika siswa yang dibelajarkan dengan media powerpoint, namun dalam pelaksanaannya kedua media pembelajaran ini telah mampu meningkatkan pemahaman dan hasil belajar Fisika siswa. Keefektifan penggunaan media pembelajaran interaktif adalah sebesar $86,13 \%$ dan interaktif sebesar $71,00 \%$.

\section{PENUTUP}

\section{Simpulan}

Berdasarkan rumusan, tujuan, hasil dan pembahasan penelitian pengembangan media pembelajaran interaktif yang dikemukakan sebelumnya maka dapat disimpulkan sebagai berikut:

1) Hasil validasi dari ahli materi terhadap media pembelajaran interaktif mata pelajaran Fisika yang dikembangkan menunjukkan bahwa; (1) kualitas materi pembelajaran dinilai sangat baik dengan persentase rata-rata sebesar

$91,25 \%$, (2) kualitas strategi pembelajaran dinilai sangat baik dengan persentase ratarata sebesar 90,00\%, (3) kualitas sistem penyampaian pembelajaran dinilai sangat baik dengan persentase rata-rata sebesar 95,00\%. Dengan demikian media pembelajaran interaktif mata pelajaran yang dikembangkan dengan menggunakan program Macromedia Flash Professioanl 8.0 secara keseluruhan termasuk dalam kategori "Sangat Baik".

2) Hasil validasi dari ahli desain pembelajaran terhadap media pembelajaran interaktif mata pelajaran Fisika yang dikembangkan dengan menggunakan program Macromedia Flash Professional 8.0 menunjukkan bahwa; (1)

kualitas desain pembelajaran dinilai sangat baik dengan persentase rata-rata $87,50 \%$, (2) kualitas desain informasi dinilai sangat baik dengan persentase ratarata sebesar 90,00\%, (3) kualitas desain interaksi dinilai baik dengan persentase rata-rata sebesar $87,50 \%$, (4) kualitas desain presentasi dinilai sangat baik dengan persentase rata-rata sebesar $83,00 \%$. Berdasarkan hasil validasi tersebut disimpulkan bahwa media pembelajaran interaktif mata pelajaran Fisika yang dikembangkan termasuk dalam kriteria sangat baik sehingga dapat diterima dan layak digunakan dalam proses pembelajaran.

3) Hasil validasi dari ahli rekayasa perangkat lunak terhadap media pembelajaran interaktif mata pelajaran Fisika yang dikembangkan dengan program Macromedia Flash Professioanal 8.0 dinyatakan bahwa; (1) pemprograman dinilai sangat baik dengan persentase ratarata sebesar $91,25 \%$, (2) kualitas teknis/tampilan dinilai sangat baik dengan persentase rata-rata sebesar $92,90 \%$. Dengan demikian media pembelajaran interaktif yang dikembangkan secara keseluruhan termasuk dalam kriteria sangat baik.

4) Menurut tanggapan uji perorangan (uji satu- satu) peserta didik pada uji coba perorangan dinyatakan bahwa media pembelajaran interaktif yang dikembangkan dengan program Macromedia Flash Professional 8.0 termasuk kategori sangat baik dimana aspek materi pembelajaran dinilai dengan persentase rata-rata sebesar $90,00 \%$ dan kualitas teknis tampilan sebesar 96,20\%.

5) Menurut tanggapan siswa pada uji coba kelompok kecil dinyatakan bahwa media pembelajaran interaktif yang dikembangkan dengan program Macromedia Flash Professional 8.0 termasuk kategori sangat baik dimana 
aspek materi pembelajaran dinilai dengan persentase rata-rata sebesar $97,22 \%$ dan kualitas teknis tampilan sebesar $96,34 \%$.

6) Menurut tanggapan siswa pada uji coba lapangan dinyatakan bahwa media pembelajaran interaktif yang dikembangkan dengan program Macromedia Flash Professional 8.0 termasuk kategori sangat baik dimana aspek materi pembelajaran dinilai dengan persentase rata-rata sebesar $94,87 \%$ dan kualitas teknis tampilan sebesar 94,96\%. Media pembelajaran yang dikembangkan peneliti layak untuk digunakan sebagai media pembelajaran Fisika.

\section{Saran}

Berdasarkan hasil temuan yang telah diuraikan pada kesimpulan serta implikasi hasil penelitian, berikut ini diajukan beberapa saran yaitu:

1. Mengingat selama ini proses pembelajaran masih menggunakan media pembelajaran powerpoint, maka disarankan agar media pembelajaran interaktif digunakan karena media pembelajaran interaktif mampu memberi umpan balik yang lebih baik bagi siswa.

2. Disarankan kepada guru agar memberi motivasi kepada siswa untuk belajar mandiri dengan menggunakan media pembelajaran interaktif, karena siswa akan mendapatkan informasi yang mereka inginkan melalui media pembelajaran interaktif ini dan mereka juga tidak perlu tergantung pada kehadiran guru dalam upaya meningkatkan hasil belajarnya.

3. Mengingat hasil kesimpulan dalam penelitian ini masih memungkinkan dipengaruhi oleh faktor-faktor yang belum mampu terkontrol, maka masih perlu kiranya dilakukan penelitian lebih lanjut pada sampel yang lebih banyak dan luas.

\section{DAFTAR PUSTAKA}

AECT. (1977). Definisi teknologi pendidikan (satuan tugas definisi \& terminologi AECT). Jakarta : Rajawali.

Anas, Yusuf. (2007). Pembelajaran dan Instruksi pendidikan. Yogyakarta: IRCiSoD.

Andrisa. (2007). Student Guide Series Macromedia Flash. Jakarta : PT Elex Media Komputindo Gramedia.

Arikunto, S. (2005). Dasar-dasar Evaluasi Pendidikan. Jakarta : Bumi Aksara.
Arsyad, A.(2002). Media Pembelajaran, Jakarta : PT Raja Grafindo Persada.

Atwi Suparman, M. (2001). Desain instruksional. Pusat antar Universitas untuk Peningkatan dan Pengembangan Aktivitas Instruksional. Jakarta: Direktorat Jenderal Pendidkan Tinggi, Departemen Pendidikan Tinggi.

Borg, W. \&V Gall, M.D. (2005). Applying Educational Research $\left(5^{\text {th }} e d\right)$. USA.

Dick, W. dan Carey, L. (2005). The systematic design of instruction. United States of America: Scott Foresman and Company.

DISA. (2010). Perkembangan Pendidikan IPA di Indonesia. Pdf-Adobe Reader http://princesrere.files.wordpress.com/ (diunduh : 20 oktober 2011).

Eltariza, Nova. (2011). Model Pembelajaran dengan Media Pembelajaran Berbasis Blog Untuk Meningkatkan Hasil Belajar Menggambar Animasi Siswa Pada Mata Pelajaran Dasar Macromedia Flash 8. Jurnal Teknologi Pendidikan, (online), vol 10 No. 2, (http://jurnal-teknologipendidikan.tp.ac.id/author/Nova Eltariza, diakses 13 Januari 2012.

Ganawati, sudarma, dkk. (2008). Ilmu Pengetahuan Alam IX. Jakarta: Depdiknas.

Hadi, amirul,dkk. (2005). Teknik Mengajar Secara Sistematis. Jakarta: Rineka Cipta.

Hamzah B. Uno.(2008). Perencanaan Pembelajaran. Jakarta: PT Bumi Aksara.

Hurriyah, Nailatil. (2010). Pengembangan Media Komputer Pembelajaran Pengembangan Media Komputer Pembelajaran Pada Mata Pelajaran Sains Tentang Struktur Bumi Untuk Siswa Kelas 5 SD Khadijah 1 Surabaya. Jurnal Teknologi Pendidikan, (online), vol 10 No. 2, (http://jurnal-teknologipendidikan.tp.ac.id/author/Nailatil Hurriyah, diakses 13 Januari 2012.

Kuswanti, sudarma dkk,. (2008). Ilmu Pengetahuan Alam IX. Jakarta: Depdiknas.

Kristanta, Arif. (2011).Visualisasi Proses Fisika Nonvisible dengan Menggunakan Macromedia Flash sebagai Usaha Meningkatkan Pemahaman Siswa tentang Konsep Listrik Statis, Pdf-Adobe Readar (Diunduh 12 desember 2011).

Kristianto, Andi.2010. Pengembangan Media Komputer Pembelajaran Multimedia Mata Pelajaran Fisika Pokok Bahasan 
Sistem Tata Surya Bagi Siswa Kelas 2 Semester I Di SMAN 22 Surabaya, (online), vol 10 No.1, (http://jurnalteknologi-

pendidikan.tp.ac.id/author/andi-kristanto, diakses 13 Januari 2012).

Lukmanul, Hakim. (2003). Teknik jitu menguasai macromedia flashProfessional 8.0. Jakarta: Elex Media Komputindo.

Miarso, Yusufhadi. (2004). Menyemai Benih Teknologi Pendidikan. Jakarta: Pustekkom.

Oktaviany, Reny Eka. (2010). Pengembangan Media Komputer Pembelajaran Tentang Arah Mata angin Mata Pelajaran IPA Siswa Kelas III SD Darul Ilmi Surabaya (online), vol 10 No. 2, (http://jurnalteknologi-

pendidikan.tp.ac.id/author/Reny $\quad$ Eka Oktaviany, diakses 13 Januari 2012.

Sadiman, Arief, dkk. (2008). Media Pendidikan: Pengertian, Pengembangan dan Pemanfaatannya. Jakarta .Seri Pustaka Teknologi Pendidikan No.6. Rajawali.

Saroso, S. (2008). Upaya Pengembangan Pendidikan Melalui Pembelajaran Berbasis

Multimedia,http://media.diknas.go.id/me dia/document/5650.pdf (Diunduh 12 desember 2011).

Sudibyo, wahono, dkk. (2008). Ilmu Pengetahuan Alam IX. Jakarta: Depdiknas.

Sukmadinata, nana. (2002). Pengembangan Kurikulum: Teori dan Praktek. Bandung: PT Remaja Rosdakarya.

Wariyono, muharomah. (2008). Ilmu Alam Sekitar 3. Jakarta: Depdiknas 